\title{
Postechiella marina gen. nov., sp. nov., isolated from seawater
}

Correspondence

Sun Bok Lee

sblee@postech.ac.kr
Dong-Heon Lee, ${ }^{1}$ Sun Ja Cho, ${ }^{1}$ Suk Min Kim ${ }^{1}$ and Sun Bok Lee ${ }^{1,2}$

\author{
${ }^{1}$ Department of Chemical Engineering, Pohang University of Science and Technology, San 31, \\ Hyoja-Dong, Pohang 790-784, Republic of Korea \\ ${ }^{2}$ Gyeongbuk Sea Grant Institute, Pohang University of Science and Technology, San 31, \\ Hyoja-Dong, Pohang 790-784, Republic of Korea
}

The family Flavobacteriaceae was first proposed by Jooste (1985) and subsequently described and emended by Bernardet et al. (1996, 2002). This family is one of the major phylogenetic lineages within the phylum Bacteroidetes (Garrity \& Holt, 2001). At the time of writing, the family comprised more than 90 recognized genera (http://www. bacterio.cict.fr/). Many members of this family were isolated from various marine environments and Antarctic habitats (Bowman et al., 1997, 1998; Bowman, 2000; Bowman \& Nichols, 2002, 2005; Cho \& Giovannoni, 2004; Nedashkovskaya et al., 2004; Nichols et al., 2005; Pinhassi et al., 2006). These bacteria are known to play an important role in the uptake and degradation of complex dissolved and particulate organic matter in marine ecosystems (Kirchman, 2002). In the course of investigations of bacterial diversity in seawater, a novel yellow-pigmented bacterium, designated strain $\mathrm{M} 091^{\mathrm{T}}$, was isolated from a seawater sample collected at Damupo beach in Pohang, Korea. On the basis of phylogenetic analysis, strain $\mathrm{M} 091^{\mathrm{T}}$ formed a distinct cluster closely related to members of the genera Flaviramulus,

The GenBank accession number for the 16S rRNA gene sequence of strain $M 091^{\top}$ is HO336487.

Three supplementary figures are available with the online version of this paper.
Algibacter, Mariniflexile, Winogradskyella, Lacinutrix and Tamlana of the phylum Bacteroidetes. The taxonomic characterization of strain $\mathrm{M} 091^{\mathrm{T}}$, using a polyphasic approach, is described in this report.

Strain $\mathrm{M} 091^{\mathrm{T}}$ was isolated from seawater collected at Damupo beach in Pohang, Republic of Korea ( $36^{\circ} 1^{\prime} 55.01^{\prime \prime}$ $\mathrm{N} 129^{\circ} 34^{\prime} 50.98^{\prime \prime} \mathrm{E}$ ), by using a standard serial dilution plating technique on marine agar 2216 (MA; Difco). The strain was initially grown at $25{ }^{\circ} \mathrm{C}$ for 5 days and then routinely maintained on MA, with subculture every 3 days, under aerobic conditions at $25{ }^{\circ} \mathrm{C}$. The strain was also stored at $-80{ }^{\circ} \mathrm{C}$ in marine broth (MB; Difco) supplemented with $20 \%(\mathrm{v} / \mathrm{v})$ glycerol.

In the phenotypic and chemotaxonomic comparisons, Flaviramulus basaltis DSM $18180^{\mathrm{T}}$ (Einen \& Øvreås, 2006), Algibacter lectus KCTC $12103^{\mathrm{T}}$ (Nedashkovskaya et al., 2004), Algibacter mikhailovii KCTC $12710^{\mathrm{T}}$ (Nedashkovskaya et al., 2007), Mariniflexile gromovii KCTC $12570^{\mathrm{T}}$ (Nedashkovskaya et al., 2006), Mariniflexile fucanivorans DSM $18792^{\mathrm{T}}$ (Barbeyron et al., 2008), Tamlana crocina KCTC $12721^{\mathrm{T}}$ (Lee, 2007), Tamlana agarivorans KCTC $22176^{\mathrm{T}}$ (Yoon et al., 2008), Gaetbulibacter saemankumensis KCTC $12379^{\mathrm{T}}$ (Jung et al., 2005); Gaetbulibacter marinus KCCM $42380^{\mathrm{T}}$ (Yang \& Cho, 2008), Yeosuana aromativorans KCCM 42019 ${ }^{\mathrm{T}}$ (Kwon 
et al., 2006) and strains representing six members of the genus Winogradskyella [W. thalassocola (Nedashkovskaya et al., 2005), W. epiphytica (Nedashkovskaya et al., 2005), W. eximia (Nedashkovskaya et al., 2005), W. rapida (Pinhassi et al., 2009), W. arenosi (Romanenko et al., 2009) and W. echinorum (Nedashkovskaya et al., 2009)] were used for reference.

Genomic DNA of strain $\mathrm{M}_{091^{\mathrm{T}}}$ was extracted and purified with an Exgene genomic extraction kit (GeneAll Biotechnology) before the nearly-complete 16S rRNA gene sequence was amplified using the bacterial universal primers 27F and 1492R (Weisburg et al., 1991). The PCR product was purified with an Expin DNA purification kit (GeneAll Biotechnology) and then ligated into a T-Blunt vector (SolGent) according to the vector manufacturer's instructions. The ligation product was transformed into competent Escherichia coli DH5 $\alpha$ cells. The cloned $16 \mathrm{~S}$ rRNA gene sequence was then sequenced on an automated sequencer (ABI3730XL; Applied Biosystems) at Macrogen Co. Ltd. The almost-complete 16S rRNA gene sequence (1444 bp) of strain M091 ${ }^{\mathrm{T}}$ was obtained and compared with the 16S rRNA gene sequences available in GenBank. The BLAST program (http://www.ncbi.nlm.nih.gov/blast/) was used to determine the approximate phylogenetic affiliation of the novel strain while the CLUSTAL_X software (Thompson et al., 1997) was used to align the sequences of closely related organisms. Sequence similarity values were computed using the EzTaxon server (http://www.eztaxon. org/; Chun et al., 2007). Gaps at the $5^{\prime}$ and $3^{\prime}$ ends and ambiguous bases were removed from the alignments using BioEdit (Hall, 2007). Phylogenetic trees, each based on comparison of $1283 \mathrm{bp}$ from each strain, were constructed using the neighbour-joining, maximum-parsimony and maximum-likelihood algorithms and the MEGA 5 software package (Kumar et al., 2008), with bootstrap values based on 1000 replications (Felsenstein, 1985). Evolutionary distance matrices were calculated according to the Kimura two-parameter model (Kimura, 1983).

The phylogenetic analyses based on 16S rRNA gene sequences indicated that strain $\mathrm{M} 091^{\mathrm{T}}$ should be placed within the family Flavobacteriaceae of the phylum Bacteroidetes, although the novel strain appeared distinct from any recognized species in the family Flavobacteriaceae (Fig. 1). In the neighbour-joining (Fig. 1) and maximumparasimony trees (see Fig. S1, available in IJSEM Online), strain $\mathrm{M} 091^{\mathrm{T}}$ joined the phylogenetic lineage of $F$. basaltis $\mathrm{H} 35^{\mathrm{T}}$, albeit with a low bootstrap value $(32 \%)$. In the maximum-likelihood tree (Fig. S2), however, the novel strain formed a phyletic clade with members of the genus Winogradskyella. In the pairwise comparisons of $16 \mathrm{~S}$ rRNA gene sequences, strain M091 ${ }^{\mathrm{T}}$ appeared most closely related to F. basaltis $\mathrm{H} 35^{\mathrm{T}}$ ( $95.1 \%$ sequence similarity; Einen \& Øvreås, 2006), followed by A. mikhailovii LMG $23988^{\mathrm{T}}$ (94.9\%; Nedashkovskaya et al., 2007), M. fucanivorans SW5 $^{\mathrm{T}}$ (94.8\%; Barbeyron et al., 2008), W. thalassocola KMM $3907^{\mathrm{T}}$ (94.7\%; Nedashkovskaya et al., 2005), L. algicola $\operatorname{AKS}_{293}{ }^{\mathrm{T}}$ (94.7\%; Nedashkovskaya et al., 2008) and T. agarivorans JW-26 ${ }^{\mathrm{T}}$ (94.7\%; Yoon et al., 2008).
Cells of strain M091 ${ }^{\mathrm{T}}$ grown aerobically on MA at $25{ }^{\circ} \mathrm{C}$ for 5 days were used for the examination of colony morphology, size and colour. Cell morphology and size were explored under a light microscope (FDX-35; Nikon,) and in a transmission electron microscope (JEM-1010; JEOL), using the methods described by Jeon et al. (2004). Gliding motility was investigated using phase-contrast light microscopy and the hanging drop method described by Bernardet et al. (2002).

The following tests were performed on strain $\mathrm{M} 091^{\mathrm{T}}$ and the reference strains. The optimal temperature and temperature range for growth were tested on MA at 4, 10, 15, 20, 25, 30, 35,37 and $42{ }^{\circ} \mathrm{C} . \mathrm{NaCl}$ requirement and tolerance were determined on synthetic Zobell agar medium (ZoBell, 1941) that contained $5 \mathrm{~g}$ Bacto peptone, $1 \mathrm{~g}$ yeast extract, $0.1 \mathrm{~g}$ ferric citrate and $15 \mathrm{~g}$ Bacto agar per litre modified artificial seawater; the modified artificial seawater contained $\left(1^{-1}\right): 0$ $100 \mathrm{~g} \mathrm{NaCl}, 5.94 \mathrm{~g} \mathrm{MgSO}_{4} .7 \mathrm{H}_{2} \mathrm{O}, 4.53 \mathrm{~g} \mathrm{MgCl}_{2} .6 \mathrm{H}_{2} \mathrm{O}$, $0.64 \mathrm{~g} \mathrm{KCl}$ and $1.3 \mathrm{~g} \mathrm{CaCl}_{2}$. The $\mathrm{pH}$ range for growth was determined in marine broth 2216 (MB, Difco) that was adjusted to $\mathrm{pH}$ values between 4.0 and 11.0 (at intervals of $0.5 \mathrm{pH}$ unit), with $\mathrm{HCl}$ or $\mathrm{NaOH}$, after sterilization. Gram staining was determined by using the bioMérieux Gram stain kit according to the manufacturer's instructions. To detect flexirubin-type pigments, cell mass was subjected to $\mathrm{KOH}$ testing, as described by Bernardet et al. (2002). Anaerobic growth was assessed on MA incubated in a GasPak anaerobic system (BBL) for up to 20 days at $25{ }^{\circ} \mathrm{C}$. Catalase and oxidase activities were determined using standard methods (Tindall et al., 2007). The degradation of agar, starch and carboxymethylcellulose were tested according to the methods of Smibert \& Krieg (1994). Casein hydrolysis was determined according to the method of Norris et al. (1985) while hydrolysis of chitin and Tweens 20, 40, 60 and 80 was determined according to Baumann \& Baumann (1981). DNase activity was determined with DNase test agar (Difco). Antibiotic sensitivity was explored by using the disc diffusion method and antibiotic discs (Oxoid) containing ampicillin $(10 \mu \mathrm{g})$, carbenicillin $(100 \mu \mathrm{g})$, chloramphenicol $(30 \mu \mathrm{g})$ erythromycin $(15 \mu \mathrm{g})$, gentamicin $(10 \mu \mathrm{g})$, kanamycin $(30 \mu \mathrm{g})$, lincomycin $(15 \mu \mathrm{g})$, nalidixic acid $(30 \mu \mathrm{g})$, neomycin $(30 \mu \mathrm{g})$, novobiocin $(5 \mu \mathrm{g})$, oleandomycin $(15 \mu \mathrm{g})$, penicillin $(10 \mathrm{U})$, polymyxin B $(300 \mu \mathrm{g})$, rifampicin $(5 \mu \mathrm{g})$, streptomycin $(25 \mu \mathrm{g})$ or tetracycline $(30 \mu \mathrm{g})$. The results were interpreted as described in the guidelines of the Clinical and Laboratory Standards Institute (CLSI, 2003). API 20E, API 20NE and API ZYM kits (bioMérieux), with incubation at $25{ }^{\circ} \mathrm{C}$ for 5 days, 5 days and $12 \mathrm{~h}$, respectively, were used to explore other phenotypic characteristics and enzyme activities of strain $\mathrm{M} 091^{\mathrm{T}}$ and the reference strains. Acid production from carbohydrates and the oxidation of different carbon sources were assessed using API 50CH kits (bioMérieux) and GN2 MicroPlates (Biolog) according to the manufacturers' instructions. All commercial kits were inoculated with bacterial suspensions containing 3\%(w/v) sea salts. The detailed results of the morphological, physiological and 


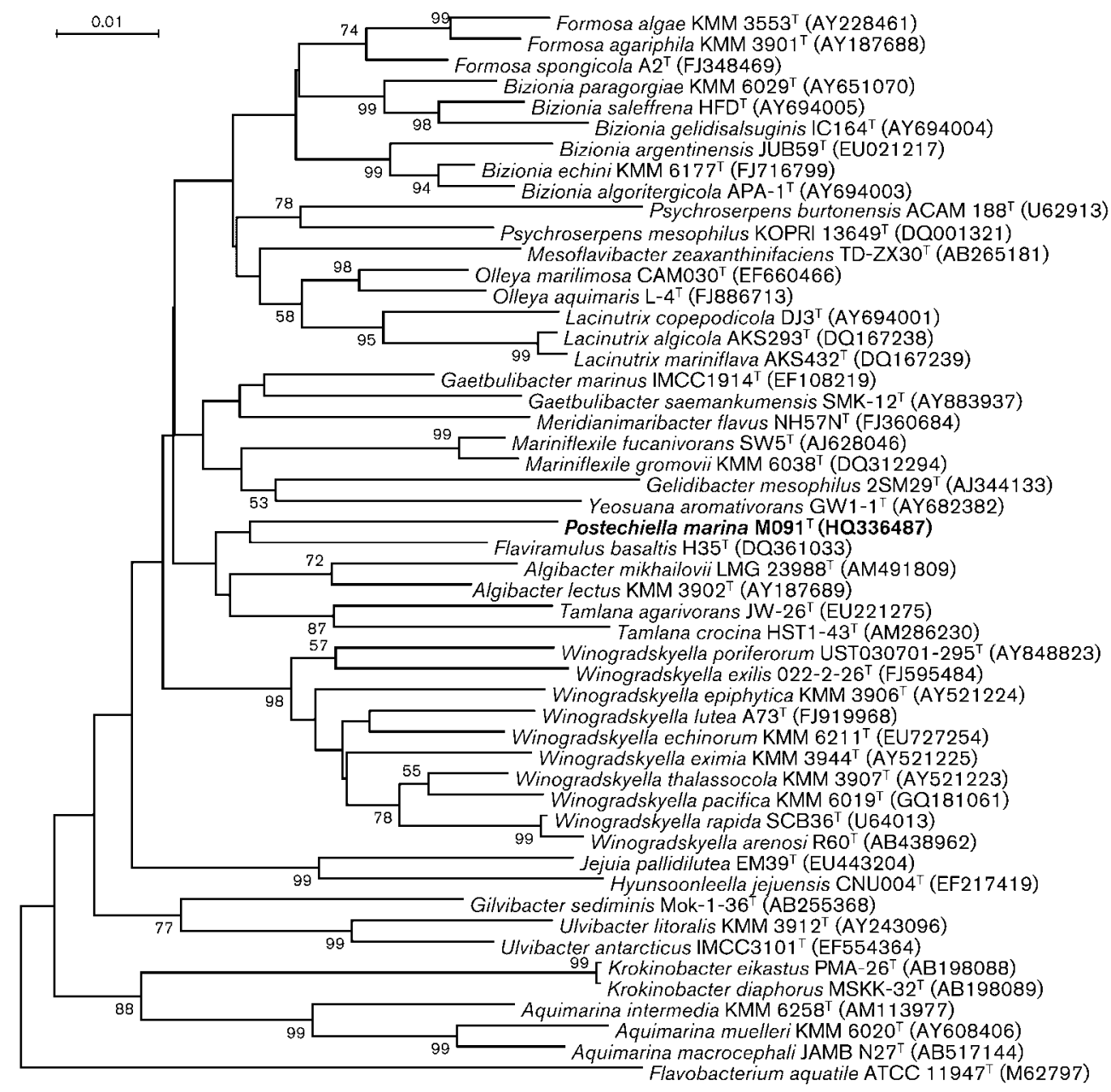

Fig. 1. Neighbour-joining phylogenetic tree based on $16 \mathrm{~S}$ rRNA gene sequences, showing the relationship of strain M091 ${ }^{\top}$ with representative members of the family Flavobacteriaceae. Bootstrap percentages $(>50 \%)$ based on 1000 replicates are shown at branch points. Flavobacterium aquatile ATCC $11947^{\top}$ was used as an outgroup. Bar, 0.01 substitution per nucleotide position.

biochemical tests are given in the genus and species descriptions and in Table 1.

For cellular fatty acid analysis, cells of strain $\mathrm{M} 091^{\mathrm{T}}$ and the reference strains were grown aerobically on MA at $25{ }^{\circ} \mathrm{C}$ for 3 days. Fatty acid methyl esters were obtained by saponification, methylation, and extraction according to the standard protocol of version 6.1 of the Sherlock Microbial Identification System (MIDI). Fatty acids were separated on a gas chromatograph (7890A; Agilent) and identified using version 6.0 of the TSBA database. The major respiratory quinone of strain $\mathrm{M} 091^{\mathrm{T}}$ was analysed as described previously (Minnikin et al., 1984; Komagata \& Suzuki, 1987). Polar lipids were extracted according to the procedures described by Minnikin et al. (1984) and separated by two-dimensional TLC using silica gel $60 \mathrm{~F}_{254}$ plates (Merck). Individual polar lipids were identified by spraying with the appropriate detection reagents and by co-migration with authentic standards
(Sigma) (Komagata \& Suzuki, 1987). The G + C content of the genomic DNA of strain M091 ${ }^{\mathrm{T}}$ was determined by using the thermal denaturation method (Marmur \& Doty, 1962), an Ultrospec 2100 spectrophotometer (Pharmacia Biotech) and, as a control, DNA from E. coli $\mathrm{K}-12$.

The major cellular fatty acids of strain $\mathrm{M} 091^{\mathrm{T}}$ were iso$\mathrm{C}_{15: 0}(20.5 \%)$, iso- $\mathrm{C}_{17: 0} 3-\mathrm{OH}(15.4 \%)$, iso- $\mathrm{C}_{15: 0} 3-\mathrm{OH}$ $(12.4 \%), \mathrm{C}_{15: 0}(10.9 \%)$ and iso- $\mathrm{C}_{15: 1} \mathrm{G}(9.9 \%)$. Such a fatty acid profile is characteristic of members of the family Flavobacteriaceae (Bernardet et al., 2002). Although, overall, the reference strains grown under the same conditions showed similar fatty acid profiles, the respective proportions of several fatty acids could be used to differentiate strain $\mathrm{M} 091^{\mathrm{T}}$ from all of its closest phylogenetic neighbours (Table 2). The major respiratory quinone of strain ${\mathrm{M} 091^{\mathrm{T}}}^{\mathrm{T}}$ was menaquinone-6 (MK-6), as seen in all recognized members of the family Flavobacteriaceae 
Table 1. Phenotypic characteristics that differentiate strain $M 091^{\top}$ from phylogenetically related genera in the family Flavobacteriaceae

Taxa: 1, strain M091 ${ }^{\mathrm{T}}$; 2, F. basaltis DSM $18180^{\mathrm{T}}$ (data from Einen \& Øvreås, 2006); 3, Algibacter [A. lectus KCTC $12103^{\mathrm{T}}$ (Nedashkovskaya et al., 2004) and A. mikhailovii KCTC $12710^{\mathrm{T}}$ (Nedashkovskaya et al., 2007)]; 4, Mariniflexile [M. fucanivorans DSM 18792 ${ }^{\mathrm{T}}$ (Barbeyron et al., 2008) and M. gromovii KCTC $12570^{\mathrm{T}}$ (Nedashkovskaya et al., 2006)]; 5, Tamlana [T. agarivorans KCTC 22176 ${ }^{\mathrm{T}}$ (Yoon et al., 2008) and T. crocina KCTC $12721^{\mathrm{T}}$ (Lee, 2007)]; 6, Gaetbulibacter [G. saemankumensis KCTC $12379^{\mathrm{T}}$ (Jung et al., 2005) and G. marinus KCCM $42380^{\mathrm{T}}$ (Yang \& Cho, 2008)]; 7, Y. aromativorans KCCM $42019^{\mathrm{T}}$ (Kwon et al., 2006); 8, Winogradskyella [W. thalassocola (Nedashkovskaya et al., 2005), W. epiphytica (Nedashkovskaya et al., 2005), W. eximia (Nedashkovskaya et al., 2005), W. poriferorum (Lau et al., 2005), W. rapida (Pinhassi et al., 2009), W. arenosi (Romanenko et al., 2009), W. echinorum (Nedashkovskaya et al., 2009), W. exilis (Ivanova et al., 2010), W. pacifica (Kim \& Nedashkovskaya, 2010) and W. lutea (Yoon et al., 2011)]. All data for taxa 1, 2, 3, 4 and 5 are from this study except those on respiratory quinones, DNA G $+\mathrm{C}$ contents and acid production from carbohydrates, which were from the literature. +, Positive; -, negative; w, weakly positive; ND, not determined; v, variable.

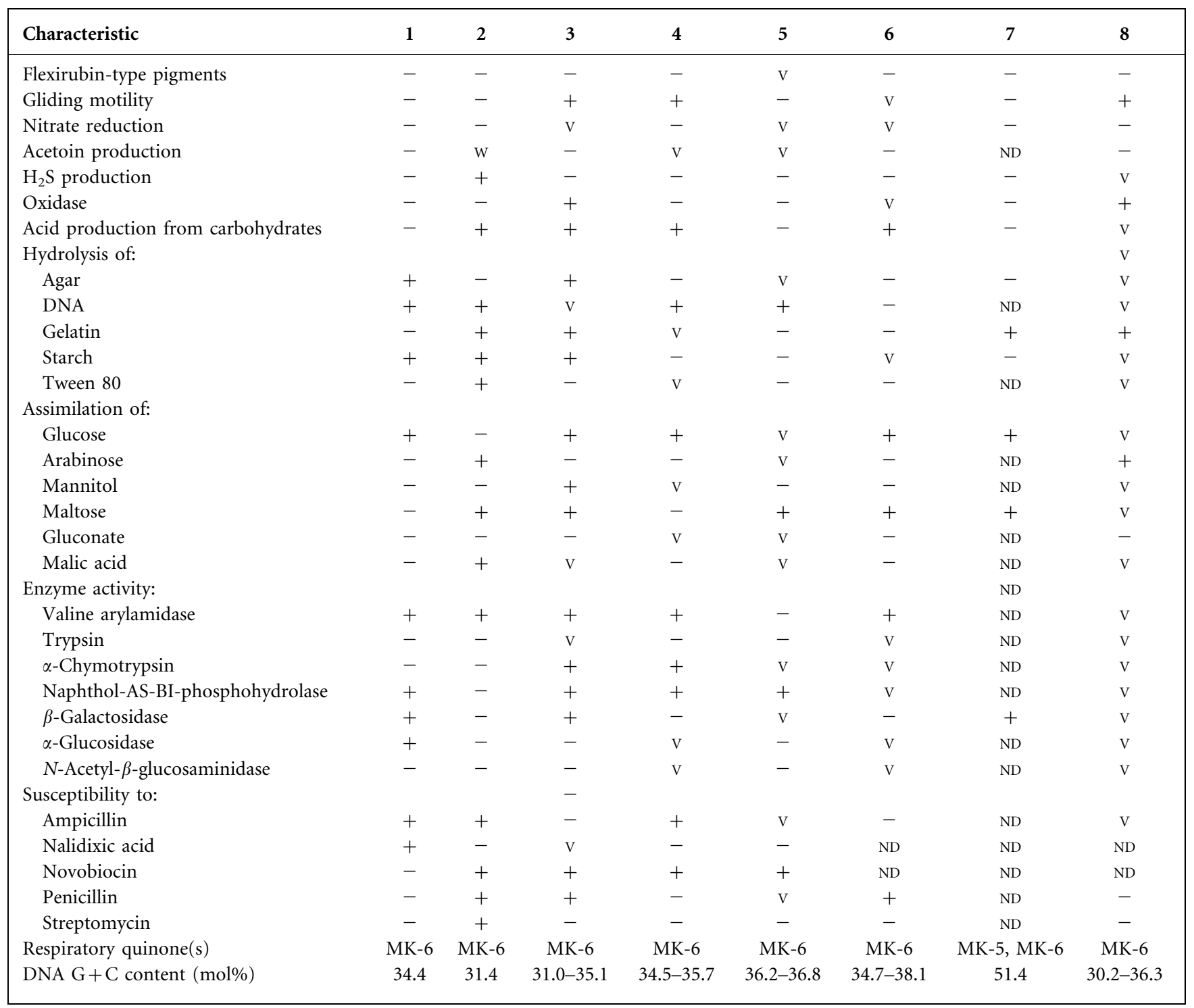

(Bernardet \& Nakagawa, 2006). The polar lipid profile of strain $\mathrm{M} 091^{\mathrm{T}}$ comprised phosphatidylethanolamine, two unidentified aminolipids, one unidentified phospholipid and seven unidentified lipids (Fig. S3). Although the major polar lipids of strain $\mathrm{M} 091^{\mathrm{T}}$ were similar to those of F. basaltis DSM $18180^{\mathrm{T}}$ (both containing phosphatidylethanolamine and the unidentified lipids L1 and L2), some of the unidentified polar lipids found in the novel strain
(PL, AL1, AL2 and L3-L7) were not detected in F. basaltis DSM $18180^{\mathrm{T}}$ and, conversely, three unidentified lipids found in F. basaltis DSM $18180^{\mathrm{T}}$ (AL, L3 and L4) were not seen in the novel strain. The genomic DNA G $+\mathrm{C}$ content of strain $\mathrm{M} 091^{\mathrm{T}}, 34.4 \mathrm{~mol} \%$, was close to corresponding values reported for M. fucanivorans DSM $18792^{\mathrm{T}}(34.5$ mol\%; Barbeyron et al., 2008) and A. mikhailovii KCTC $12710^{\mathrm{T}}$ (35.1 mol\%; Nedashkovskaya et al., 2007) and 
Table 2. Cellular fatty acid composition (\%) of strain $M 091^{\top}$ and phylogenetically related genera in the family Flavobacteriaceae

Taxa: 1, strain M091 ${ }^{\mathrm{T}}$; 2, F. basaltis DSM $18180^{\mathrm{T}}$; 3, Algibacter (A. lectus KCTC $12103^{\mathrm{T}}$ and A. mikhailovii KCTC $12710^{\mathrm{T}}$ ); 4, Mariniflexile $($ M. fucanivorans DSM $18792^{\mathrm{T}}$ and M. gromovii KCTC $12570^{\mathrm{T}}$ ); 5, Tamlana (T. agarivorans KCTC $22176^{\mathrm{T}}$ and T. crocina KCTC $12721^{\mathrm{T}}$ ); 6 , Gaetbulibacter (G. saemankumensis KCTC $12379^{\mathrm{T}}$ and G. marinus KCCM 42380 $)$; 7, Y. aromativorans KCCM 42019 ${ }^{\mathrm{T}}$; 8, Winogradskyella (W. thalassocola KCTC $12221^{\mathrm{T}}$, W. epiphytica KCTC $12220^{\mathrm{T}}$, W. eximia KCTC $12219^{\mathrm{T}}$, W. rapida CCUG $56098^{\mathrm{T}}$, W. arenosi JCM $15527^{\mathrm{T}}$ and $W$. echinorum KCTC $22026^{\mathrm{T}}$ ). All data are from this study. Fatty acids amounting to $<1.0 \%$ of the total fatty acids in all strains are not shown. tr, Trace amount $(<1.0 \%)$; - , not detected.

\begin{tabular}{|c|c|c|c|c|c|c|c|c|}
\hline Fatty acid & 1 & 2 & 3 & 4 & 5 & 6 & 7 & 8 \\
\hline \multicolumn{9}{|l|}{ Straight-chain } \\
\hline $\mathrm{C}_{15: 0}$ & 10.9 & 10.6 & $12.3-14.4$ & $4.5-14.9$ & $9.4-18.2$ & $2.1-3.5$ & 6.1 & $\operatorname{tr}-6.8$ \\
\hline $\mathrm{C}_{16: 0}$ & 4.1 & 1.2 & $1.2-1.9$ & $1.0-2.5$ & $1.1-1.4$ & $1.1-1.6$ & 1.1 & $\operatorname{tr}-2.1$ \\
\hline \multicolumn{9}{|l|}{ Branched } \\
\hline iso- $\mathrm{C}_{14: 0}$ & $\operatorname{tr}$ & 1.1 & $\operatorname{tr}$ & $1.3-1.9$ & $0-1.1$ & $1.3-2.1$ & 2.7 & $\operatorname{tr}-2.3$ \\
\hline iso- $\mathrm{C}_{15: 0}$ & 20.5 & 16.3 & $10.6-10.8$ & 19.8 & $19.6-26.9$ & $21.4-21.5$ & 24.1 & $7.8-25.3$ \\
\hline iso- $\mathrm{C}_{15: 1} \mathrm{G}$ & 9.9 & 20.3 & $12.1-20.3$ & $7.3-17.6$ & $13.5-15.9$ & $10.3-3.9$ & 8.7 & $7.7-14.6$ \\
\hline iso- $\mathrm{C}_{16: 0}$ & 1.0 & $\operatorname{tr}$ & $\operatorname{tr}$ & $1.5-2.3$ & $1.1-1.5$ & $\operatorname{tr}-1.7$ & 3.3 & $\operatorname{tr}-5.6$ \\
\hline iso- $\mathrm{C}_{16: 1} \mathrm{H}$ & - & - & $\operatorname{tr}$ & $\operatorname{tr}-3.3$ & $0-1.0$ & $\operatorname{tr}$ & 2.1 & $\operatorname{tr}-3.3$ \\
\hline anteiso- $\mathrm{C}_{15: 0}$ & 4.1 & 6.4 & $11.9-13.9$ & $7.0-9.5$ & $4.5-5.3$ & $5.2-9.7$ & 9.3 & $7.8-14.1$ \\
\hline anteiso- $\mathrm{C}_{15: 1} \mathrm{~A}$ & $\operatorname{tr}$ & 2.4 & $1.5-16$ & $\operatorname{tr}-1.2$ & $1.1-1.6$ & $1.4-3.2$ & $\operatorname{tr}$ & $2.3-4.9$ \\
\hline iso- $\mathrm{C}_{17: 1} \omega 9 c$ & - & - & - & - & - & $0-1.4$ & - & $0-1.5$ \\
\hline \multicolumn{9}{|l|}{ Unsaturated } \\
\hline $\mathrm{C}_{14: 1} \omega 5 c$ & - & - & - & - & $0-1.5$ & - & - & $0-1.2$ \\
\hline $\mathrm{C}_{15: 1} \omega 6 c$ & 2.0 & 1.9 & $4.1-5.2$ & $2.4-6.3$ & $4.0-7.2$ & $\operatorname{tr}$ & 1.4 & $0-1.9$ \\
\hline $\mathrm{C}_{17: 1} \omega 6 c$ & 1.2 & $\operatorname{tr}$ & $2.6-3.5$ & $\operatorname{tr}-2.2$ & $2.3-2.5$ & $\operatorname{tr}-1.0$ & $\operatorname{tr}$ & $\operatorname{tr}-1.1$ \\
\hline $\mathrm{C}_{18: 1} \omega 5 c$ & 1.7 & 1.0 & 1.1 & $\operatorname{tr}-1.3$ & - & $\operatorname{tr}$ & $\operatorname{tr}$ & $\operatorname{tr}-2.8$ \\
\hline \multicolumn{9}{|l|}{ Hydroxy } \\
\hline $\mathrm{C}_{15: 0} 2-\mathrm{OH}$ & $\operatorname{tr}$ & 1.6 & 1.9 & $1.7-1.8$ & $1.1-1.3$ & $\operatorname{tr}-1.8$ & 1.7 & $1.5-2.9$ \\
\hline $\mathrm{C}_{17: 0} 2-\mathrm{OH}$ & $\operatorname{tr}$ & 1.4 & $2.0--2.4$ & $1.6-2.5$ & $1.2-2.7$ & $1.7-3.2$ & 2.0 & $2.6-7.6$ \\
\hline $\mathrm{C}_{15: 0} 3-\mathrm{OH}$ & 2.1 & 3.2 & $2.9-3.0$ & $1.9-3.6$ & $1.6-3.7$ & $\operatorname{tr}$ & 1.7 & $0-1.4$ \\
\hline $\mathrm{C}_{16: 0} 3-\mathrm{OH}$ & 2.8 & 1.2 & $2.1-2.6$ & $\operatorname{tr}-1.5$ & $\operatorname{tr}-4.0$ & $\operatorname{tr}-1.1$ & $\operatorname{tr}$ & $0-1.3$ \\
\hline $\mathrm{C}_{17: 0} 3-\mathrm{OH}$ & 1.2 & - & 1.8 & $0-1.2$ & $0-1.4$ & 0.58 & - & - \\
\hline iso- $\mathrm{C}_{15: 0} 3-\mathrm{OH}$ & 12.4 & 13.2 & $9.7-10.4$ & $5.8-6.2$ & $5.3-5.7$ & $6.0-7.4$ & 3.9 & $2.6-13.9$ \\
\hline iso- $\mathrm{C}_{16: 0} 3-\mathrm{OH}$ & 4.8 & 5.9 & $3.3-3.4$ & $5.2-7.7$ & $2.2-8.5$ & $2.5-8.4$ & 9.6 & $6.1-20.3$ \\
\hline iso- $\mathrm{C}_{17: 0} 3-\mathrm{OH}$ & 15.4 & 13.4 & $12.3-13.6$ & $8.5-14.2$ & $14.4-18.6$ & $9.8-16.9$ & 10.5 & $6.9-12.7$ \\
\hline $\mathrm{C}_{18: 0}$ 10-methyl, TBSA & - & - & 1.1 & - & - & - & - & - \\
\hline \multicolumn{9}{|l|}{ Summed feature } \\
\hline 3 & 8.4 & 5.3 & $6.3-6.5$ & $7.5-8.5$ & $4.7-5.2$ & $2.9-10.7$ & 8.1 & $2.0-4.7$ \\
\hline 9 & - & - & - & $0-1.5$ & $\operatorname{tr}$ & $0-2.0$ & 3.7 & $1.6-2.7$ \\
\hline
\end{tabular}

*Summed features are groups of two or three fatty acids that cannot be separated by GLC using the MIDI system. Summed feature 3 comprised $\mathrm{C}_{16: 1} \omega 6 c$ and/or $\mathrm{C}_{16: 1} \omega 7 c$. Summed feature 9 comprised $\mathrm{C}_{16: 0} 10$-methyl and/or iso- $\mathrm{C}_{17: 1} \omega 9 c$.

slightly higher than the value, of $31 \mathrm{~mol} \%$, reported for $F$. basaltis DSM $18180^{\mathrm{T}}$ (Einen \& Øvreås, 2006).

The results of the phylogenetic analysis based on the $16 \mathrm{~S}$ rRNA gene sequence of strain M091 ${ }^{\mathrm{T}}$ were supported by a combination of phenotypic and chemotaxonomic characteristics (Tables 1 and 2). Strain $\mathrm{M} 091^{\mathrm{T}}$ could be clearly differentiated from $F$. basaltis by its oxidase, naphtholAS-BI-phosphohydrolase and $\beta$-galactosidase activities, its ability to assimilate glucose and hydrolyse agar, its susceptibility to nalidixic acid, and its inability to generate acids from carbohydrates or produce acetoin or $\mathrm{H}_{2} \mathrm{~S}$. Its $\alpha$ glucosidase activity, ability to hydrolyse starch, susceptibility to nalidixic acid and its lack of gliding motility distinguished strain ${\mathrm{M} 091^{\mathrm{T}}}$ from members of the genera Algibacter,
Mariniflexile and Tamlana. Strain M091 ${ }^{\mathrm{T}}$ could be differentiated from members of the genera Gaetbulibacter and Winogradskyella by its $\beta$-glucosidase activity and ability to hydrolyse agar and DNA. Strain M091 ${ }^{\mathrm{T}}$ could also be clearly distinguished from its closest phylogenetic neighbours by its fatty acid profile and the proportions of several fatty acids (Table 2). Based on the phenotypic and phylogenetic data, strain $\mathrm{M} 091^{\mathrm{T}}$ represents a novel species of a new genus in the family Flavobacteriaceae, for which the name Postechiella marina gen. nov., sp. nov. is proposed.

\section{Description of Postechiella gen. nov.}

Postechiella (Pos.te.chi'el.la. N.L. dim. fem. n. Postechiella arbitrarily developed from the acronym POSTECH formed 
from the initial letters of the Pohang University of Science and Technology, where the initial taxonomic studies on this genus were conducted).

Cells are Gram-staining-negative, non-flagellated, strictly aerobic, yellow-pigmented and rod-shaped. Gliding motility is absent. Oxidase- and catalase-positive. Cells produce nondiffusible carotenoid pigments but flexirubin pigments are absent. Cellular fatty acids are dominated by iso- $\mathrm{C}_{15: 0}$, iso$\mathrm{C}_{17: 0} 3-\mathrm{OH}$, iso- $\mathrm{C}_{15: 0} 3-\mathrm{OH}, \mathrm{C}_{15: 0}$ and iso- $\mathrm{C}_{15: 1} \mathrm{G}$. The major respiratory quinone is MK-6. The polar lipids are phosphatidylethanolamine, two unidentified aminolipids, one unidentified phospholipid and seven unidentified lipids. The genus is a member of the family Flavobacteriaceae, phylum Bacteroidetes. The type species is Postechiella marina.

\section{Description of Postechiella marina sp. nov.}

Postechiella marina (ma.ri'na. L. fem. adj. marina of or belonging to the sea, marine).

In addition to the characteristics described for the genus above, the species is distinguished by the following properties. Cells are non-motile rods measuring $0.5-0.7 \mu \mathrm{m}$ in diameter and $1.0-2.5 \mu \mathrm{m}$ in length. After incubation for 3 days, colonies on MA are circular, convex, entire, smooth, yellowcoloured and 1.0-5.0 $\mathrm{mm}$ in diameter. Growth occurs at 4$30{ }^{\circ} \mathrm{C}$ (optimum, $25{ }^{\circ} \mathrm{C}$ ), at $\mathrm{pH}$ 6.0-9.0 (optimum between $\mathrm{pH} 7.0$ and $\mathrm{pH} 8.0$ ), and with $1.0-5.0 \%(\mathrm{w} / \mathrm{v}) \mathrm{NaCl}$ (optimum, $3.0 \%$ ). Agar, DNA, starch, Tween 20, Tween 40 and Tween 60 are hydrolysed but casein, carboxymethylcellulose and Tween 80 are not. In API 20E tests, glucose is oxidized but mannitol, inositol, sorbitol, rhamnose, sucrose, melibiose, amygdalin and arabinose are not. Negative result in tests for arginine dihydrolase, lysine decarboxylase, ornithine decarboxylase, tryptophan deaminase and urease activities and for acetoin, indole and $\mathrm{H}_{2} \mathrm{~S}$ production. In API 20NE tests, aesculin is hydrolysed, $\beta$-galactosidase activity is present and glucose and mannose are assimilated but arabinose, mannitol, $\mathrm{N}$-acetyl-D-glucosamine, maltose, gluconate, caprate, adipate, malate, citrate and phenylacetate are not assimilated. Nitrate is not reduced. Negative result in tests for indole production, glucose acidification, gelatin hydrolysis and arginine dihydrolase and urease activities. Positive result, in API ZYM tests, for alkaline phosphatase, esterase (C4), esterase lipase (C8), leucine arylamidase, valine arylamidase, cystine arylamidase, acid phosphatase, naphthol-AS-BI-phosphohydrolase, $\beta$ galactosidase and $\alpha$-glucosidase activities but negative for lipase (C14), trypsin, $\alpha$-chymotrypsin, $\alpha$-galactosidase, $\beta$ glucuronidase, $\beta$-glucosidase, $N$-acetyl- $\beta$-glucosaminidase, $\alpha$-mannosidase and $\alpha$-fucosidase activities. Acid is only produced aerobically, in API $50 \mathrm{CH}$ tests, from aesculin-ferric citrate and 5-ketogluconate. $\alpha$-Cyclodextrin, dextrin, glycogen, cellobiose, D-galactose, gentiobiose, $\alpha$-D-glucose, $\alpha$-lactose, maltose, D-mannose, trehalose, acetic acid, D-glucosaminic acid, D-glucuronic acid, D-saccharic acid, L-alanyl glycine, L-asparagine, L-aspartic acid, L-glutamic acid, L-threonine, DL$\alpha$-glycerol phosphate, glucose 1-phosphate and glucose 6phosphate (but none of the other carbon sources included in the GN2 MicroPlate) are oxidized as sole carbon sources. Sensitive to ampicillin $(10 \mu \mathrm{g})$, carbenicillin $(100 \mu \mathrm{g})$, chloramphenicol $(30 \mu \mathrm{g})$, erythromycin $(15 \mu \mathrm{g})$, lincomycin $(15 \mu \mathrm{g})$, nalidixic acid $(30 \mu \mathrm{g})$, oleandomycin $(15 \mu \mathrm{g})$, rifampicin $(5 \mu \mathrm{g})$ and tetracycline $(30 \mu \mathrm{g})$, but resistant to gentamicin $(10 \mu \mathrm{g})$, kanamycin $(30 \mu \mathrm{g})$, neomycin $(30 \mu \mathrm{g})$, novobiocin $(5 \mu \mathrm{g})$, penicillin (10 IU), polymyxin B $(300 \mu \mathrm{g})$ and streptomycin $(25 \mu \mathrm{g})$.

The type strain, M091 ${ }^{\mathrm{T}}\left(=\right.$ KCTC $\left.23537^{\mathrm{T}}=\mathrm{JCM} 17630^{\mathrm{T}}\right)$, was isolated from seawater collected at Damupo beach in Pohang, Korea. The DNA G $+\mathrm{C}$ content of the type strain is $34.4 \mathrm{~mol} \%$.

\section{Acknowledgements}

This work was supported by the 21C Frontier Microbial Genomics and Applications Centre Program, Ministry of Education, Science \& Technology, Republic of Korea.

\section{References}

Barbeyron, T., L'Haridon, S., Michel, G. \& Czjzek, M. (2008). Mariniflexile fucanivorans sp. nov., a marine member of the Flavobacteriaceae that degrades sulphated fucans from brown algae. Int J Syst Evol Microbiol 58, 2107-2113.

Baumann, P. \& Baumann, L. (1981). The marine Gram-negative eubacteria: genera Photobacterium, Beneckea, Alteromonas, Pseudomonas and Alcaligenes. In The Prokaryotes, vol. 1, pp. 1302-1331. Edited by M. P. Starr, H. Stolp, H. G. Trüper, A. Balows \& H. Schlegel. Berlin: Springer.

Bernardet, J.-F. \& Nakagawa, Y. (2006). An introduction to the family Flavobacteriaceae. In The Prokaryotes. A Handbook on the Biology of Bacteria, 3rd edn, vol. 7, pp. 455-480. Edited by M. Dworkin, S. Falkow, E. Rosenberg, K. H. Schleifer \& E. Stackebrandt. New York: Springer.

Bernardet, J. F., Segers, P., Vancanneyt, M., Berthe, F., Kersters, K. \& Vandamme, P. (1996). Cutting a Gordian knot: emended classification and description of the genus Flavobacterium, emended description of the family Flavobacteriaceae, and proposal of Flavobacterium hydatis nom. rev. (basonym, Cytophaga aquatilis Strohl and Tait 1978). Int J Syst Bacteriol 46, 128-148.

Bernardet, J.-F., Nakagawa, Y., Holmes, B. \& for the Subcommittee on the taxonomy of Flavobacterium and Cytophaga-like bacteria of the International Committee on Systematics of Prokaryotes (2002). Proposed minimal standards for describing new taxa of the family Flavobacteriaceae and emended description of the family. Int $\mathrm{J}$ Syst Evol Microbiol 52, 1049-1070.

Bowman, J. P. (2000). Description of Cellulophaga algicola sp. nov., isolated from the surfaces of Antarctic algae, and reclassification of Cytophaga uliginosa (ZoBell and Upham 1944) Reichenbach 1989 as Cellulophaga uliginosa comb. nov. Int J Syst Evol Microbiol 50, 1861-1868.

Bowman, J. P. \& Nichols, D. S. (2002). Aequorivita gen. nov., a member of the family Flavobacteriaceae isolated from terrestrial and marine Antarctic habitats. Int J Syst Evol Microbiol 52, 1533-1541.

Bowman, J. P. \& Nichols, D. S. (2005). Novel members of the family Flavobacteriaceae from Antarctic maritime habitats including Subsaximicrobium wynnwilliamsii gen. nov., sp. nov., Subsaximicrobium saxinquilinus sp. nov., Subsaxibacter broadyi gen. nov., sp. nov., Lacinutrix copepodicola gen. nov., sp. nov., and novel species of the genera Bizionia, Gelidibacter and Gillisia. Int J Syst Evol Microbiol 55, 1471-1486.

Bowman, J. P., McCammon, S. A., Brown, J. L., Nichols, P. D. \& McMeekin, T. A. (1997). Psychroserpens burtonensis gen. nov., sp. nov., 
and Gelidibacter algens gen. nov., sp. nov., psychrophilic bacteria isolated from Antarctic lacustrine and sea ice habitats. Int J Syst Bacteriol 47, 670-677.

Bowman, J. P., McCammon, S. A., Lewis, T., Skerratt, J. H., Brown, J. L., Nichols, D. S. \& McMeekin, T. A. (1998). Psychroflexus torquis gen. nov., sp. nov., a psychrophilic species from Antarctic sea ice, and reclassification of Flavobacterium gondwanense (Dobson et al. 1993) as Psychroflexus gondwanense gen. nov., comb. nov. Microbiology 144, 1601-1609.

Cho, J.-C. \& Giovannoni, S. J. (2004). Robiginitalea biformata gen. nov., sp. nov., a novel marine bacterium in the family Flavobacteriaceae with a higher G $+\mathrm{C}$ content. Int J Syst Evol Microbiol 54, 1101-1106.

Chun, J., Lee, J. H., Jung, Y. Y., Kim, M. J., Kim, S. I., Kim, B. K. \& Lim, Y. W. (2007). EzTaxon: a web-based tool for the identification of prokaryotes based on $16 \mathrm{~S}$ ribosomal RNA gene sequences. Int J Syst Evol Microbiol 57, 2259-2261.

CLSI (2003). Performance standards for antimicrobial disk susceptibility tests; approved standard. CLSI document M2-A8. Wayne, PA: Clinical and Laboratory Standards Institute.

Einen, J. \& Øvreås, L. (2006). Flaviramulus basaltis gen. nov., sp. nov., a novel member of the family Flavobacteriaceae isolated from seafloor basalt. Int J Syst Evol Microbiol 56, 2455-2461.

Felsenstein, J. (1985). Confidence limits on phylogenies: an approach using the bootstrap. Evolution 39, 783-791.

Garrity, G. M. \& Holt, J. G. (2001). The road map to the Manual. In Bergey's Manual of Systematic Bacteriology, 2nd edn, pp. 119-166. Edited by D. R. Boone, R. W. Castenholz \& G. M. Garrity. New York: Springer.

Hall, T. (2007). BioEdit. Biological sequence alignment editor for Win95/ 98/NT/2K/XP. Carlsbad, CA: Ibis Biosciences.

Ivanova, E. P., Christen, R., Gorshkova, N. M., Zhukova, N. V., Kurilenko, V. V., Crawford, R. J. \& Mikhailov, V. V. (2010). Winogradskyella exilis sp. nov., isolated from the starfish Stellaster equestris, and emended description of the genus Winogradskyella. Int $J$ Syst Evol Microbiol 60, 1577-1580.

Jeon, C. O., Park, W., Ghiorse, W. C. \& Madsen, E. L. (2004). Polaromonas naphthalenivorans sp. nov., a naphthalene-degrading bacterium from naphthalene-contaminated sediment. Int J Syst Evol Microbiol 54, 93-97.

Jooste, P. J. (1985). The taxonomy and significance of FlavobacteriumCytophaga strains from dairy sources. $\mathrm{PhD}$ thesis, University of the Orange Free State, South Africa.

Jung, S. Y., Kang, S. J., Lee, M. H., Lee, S. Y., Oh, T. K. \& Yoon, J. H. (2005). Gaetbulibacter saemankumensis gen. nov., sp. nov., a novel member of the family Flavobacteriaceae isolated from a tidal flat sediment in Korea. Int J Syst Evol Microbiol 55, 1845-1849.

Kim, S. B. \& Nedashkovskaya, O. I. (2010). Winogradskyella pacifica sp. nov., a marine bacterium of the family Flavobacteriaceae. Int J Syst Evol Microbiol 60, 1948-1951.

Kimura, M. (1983). The Neutral Theory of Molecular Evolution. Cambridge: Cambridge University Press.

Kirchman, D. L. (2002). The ecology of Cytophaga-Flavobacteria in aquatic environments. FEMS Microbiol Ecol 39, 91-100.

Komagata, K. \& Suzuki, K. (1987). Lipid and cell-wall analysis in bacterial systematics. Methods Microbiol 19, 161-207.

Kumar, S., Nei, M., Dudley, J. \& Tamura, K. (2008). MEGA: a biologistcentric software for evolutionary analysis of DNA and protein sequences. Brief Bioinform 9, 299-306.

Kwon, K. K., Lee, H.-S., Jung, H.-B., Kang, J.-H. \& Kim, S.-J. (2006). Yeosuana aromativorans gen. nov., sp. nov., a mesophilic marine bacterium belonging to the family Flavobacteriaceae, isolated from estuarine sediment of the South Sea, Korea. Int J Syst Evol Microbiol 56, 727-732.

Lau, S. C. K., Tsoi, M. M. Y., Li, X., Plakhotnikova, I., Dobretsov, S., Lau, K. W. K., Wu, M., Wong, P. K., Pawlik, J. R. \& Qian, P.-Y. (2005). Winogradskyella poriferorum sp. nov., a novel member of the family Flavobacteriaceae isolated from a sponge in the Bahamas. Int J Syst Evol Microbiol 55, 1589-1592.

Lee, S. D. (2007). Tamlana crocina gen. nov., sp. nov., a marine bacterium of the family Flavobacteriaceae, isolated from beach sediment in Korea. Int J Syst Evol Microbiol 57, 764-769.

Marmur, J. \& Doty, P. (1962). Determination of the base composition of deoxyribonucleic acid from its thermal denaturation temperature. J Mol Biol 5, 109-118.

Minnikin, D. E., O'Donnell, A. G., Goodfellow, M., Alderson, G., Athalye, M., Schaal, A. \& Parlett, J. H. (1984). An integrated procedure for the extraction of bacterial isoprenoid quinones and polar lipids. J Microbiol Methods 2, 233-241.

Nedashkovskaya, O. I., Kim, S. B., Han, S. K., Lysenko, A. M., Rohde, M., Rhee, M.-S., Frolova, G. M., Falsen, E., Mikhailov, V. V. \& Bae, K. S. (2004). Maribacter gen. nov., a new member of the family Flavobacteriaceae, isolated from marine habitats, containing the species Maribacter sedimenticola sp. nov., Maribacter aquivivus sp. nov., Maribacter orientalis sp. nov. and Maribacter ulvicola sp. nov. Int J Syst Evol Microbiol 54, 1017-1023.

Nedashkovskaya, O. I., Kim, S. B., Han, S. K., Snauwaert, C., Vancanneyt, M., Swings, J., Kim, K. O., Lysenko, A. M., Rohde, M. \& other authors (2005). Winogradskyella thalassocola gen. nov., sp. nov., Winogradskyella epiphytica sp. nov. and Winogradskyella eximia sp. nov., marine bacteria of the family Flavobacteriaceae. Int J Syst Evol Microbiol 55, 49-55.

Nedashkovskaya, O. I., Kim, S. B., Kwak, J., Mikhailov, V. V. \& Bae, K. S. (2006). Mariniflexile gromovii gen. nov., sp. nov., a gliding bacterium isolated from the sea urchin Strongylocentrotus intermedius. Int J Syst Evol Microbiol 56, 1635-1638.

Nedashkovskaya, O. I., Vancanneyt, M., Kim, S. B., Hoste, B. \& Bae, K. S. (2007). Algibacter mikhailovii sp. nov., a novel marine bacterium of the family Flavobacteriaceae, and emended description of the genus Algibacter. Int J Syst Evol Microbiol 57, 2147-2150.

Nedashkovskaya, O. I., Kwon, K. K., Yang, S. H., Lee, H. S., Chung, K. H. \& Kim, S. J. (2008). Lacinutrix algicola sp. nov. and Lacinutrix mariniflava sp. nov., two novel marine alga-associated bacteria and emended description of the genus Lacinutrix. Int J Syst Evol Microbiol 58, 2694-2698.

Nedashkovskaya, O. I., Vancanneyt, M., Kim, S. B. \& Zhukova, N. V. (2009). Winogradskyella echinorum sp. nov., a marine bacterium of the family Flavobacteriaceae isolated from the sea urchin Strongylocentrotus intermedius. Int J Syst Evol Microbiol 59, 1465-1468.

Nichols, C. M., Bowman, J. P. \& Guezennec, J. (2005). Olleya marilimosa gen. nov., sp. nov., an exopolysaccharide-producing marine bacterium from the family Flavobacteriaceae, isolated from the Southern Ocean. Int J Syst Evol Microbiol 55, 1557-1561.

Norris, J. R., Ribbons, D. W. \& Varma, A. K. (editors) (1985). Methods in Microbiology, vol. 18. London: Academic Press.

Pinhassi, J., Bowman, J. P., Nedashkovskaya, O. I., Lekunberri, I., Gomez-Consarnau, L. \& Pedrós-Alió, C. (2006). Leeuwenhoekiella blandensis sp. nov., a genome-sequenced marine member of the family Flavobacteriaceae. Int J Syst Evol Microbiol 56, 1489-1493.

Pinhassi, J., Nedashkovskaya, O. I., Hagström, Å. \& Vancanneyt, M. (2009). Winogradskyella rapida sp. nov., isolated from proteinenriched seawater. Int J Syst Evol Microbiol 59, 2180-2184.

Romanenko, L. A., Tanaka, N., Frolova, G. M. \& Mikhailov, V. V. (2009). Winogradskyella arenosi sp. nov., a member of the family 
Flavobacteriaceae isolated from marine sediments from the Sea of Japan. Int J Syst Evol Microbiol 59, 1443-1446.

Smibert, R. M. \& Krieg, N. R. (1994). Phenotypic characteristics. In Methods for General and Molecular Biology, pp. 607-654. Edited by P. Gerhardt, R. G. E. Murray, W. A. Wood \& N. R. Krieg. Washington, DC: American Society for Microbiology.

Thompson, J. D., Gibson, T. J., Plewniak, F., Jeanmougin, F. \& Higgins, D. G. (1997). The CLUSTAL_X windows interface: flexible strategies for multiple sequence alignment aided by quality analysis tools. Nucleic Acids Res 25, 4876-4882.

Tindall, B. J., Sikorski, J., Simbert, R. A. \& Kreig, N. R. (2007). Phenotypic characterization and principles of comparative systematics. In Methods for General and Molecular Microbiology, pp. 330-393. Edited by C. A. Reddy, T. J. Beveridge, J. A. Breznak, G. A. Marzluf, T. M. Schmidt \& L. R. Snyder. Washington, DC: American Society for Microbiology.
Weisburg, W. G., Barns, S. M., Pelletier, D. A. \& Lane, D. J. (1991). 16S ribosomal DNA amplification for phylogenetic study. J Bacteriol 173, 697-703.

Yang, S.-J. \& Cho, J.-C. (2008). Gaetbulibacter marinus sp. nov., isolated from coastal seawater, and emended description of the genus Gaetbulibacter. Int J Syst Evol Microbiol 58, 315-318.

Yoon, J.-H., Kang, S.-J., Lee, M.-H. \& Oh, T.-K. (2008). Tamlana agarivorans sp. nov., isolated from seawater off Jeju Island in Korea. Int J Syst Evol Microbiol 58, 1892-1895.

Yoon, B.-J., Byun, H.-D., Kim, J.-Y., Lee, D.-H., Kahng, H.-Y. \& Oh, D.-C. (2011). Winogradskyella lutea sp. nov., isolated from seawater, and emended description of the genus Winogradskyella. Int J Syst Evol Microbiol 61, 1539-1543.

ZoBell, C. E. (1941). Studies on marine bacteria. I. The cultural requirements of heterotrophic aerobes. J Mar Res 4, 42-75. 